\title{
COMPARISON OF ENTREPRENEURIAL INTENTIONS AMONG STUDENTS AND EMPLOYEES
}

\author{
UDC: 005.5-057.87(497.11) \\ 005.5(497.11) \\ Original Scientific Paper
Jelena RAJKOVIĆ ${ }^{1}$, Predrag MALI ${ }^{2}$, Siniša MITIĆ ${ }^{2}$, Bogdan KUZMANOVIĆ ${ }^{2}$, Milan NIKOLIĆ ${ }^{3}$ \\ ${ }^{1}$ University "Union - Nikola Tesla”, Faculty of Engineering management, 11000 Belgrade, Bulevar vojvode Misica \\ 43, Republic of Serbia \\ ${ }^{2}$ University of Novi Sad, Faculty of Technical Science, 21000 Novi Sad, Trg Dositeja Obradovića 6, \\ Republic of Serbia \\ ${ }^{3}$ University of Novi Sad, Technical Faculty “Mihajlo Pupin”, 23000 Zrenjanin, Djure Djakovića bb, \\ Republic of Serbia \\ E-mail: mikaczr@sbb.rs
}

Paper received: 24.02.2020; Paper accepted: 21.04.2020.

\begin{abstract}
The paper tackles the comparison of entrepreneurial intentions among students and employees in Serbia. A t-test was applied to compare individual entrepreneurial orientation dimensions, achievement dimension, and theory of planned behaviour dimensions (including entrepreneurship intention dimension). The analysis also encompassed gender as the subject's control variable. The main conclusions are 1. Risk-taking dimension, Proactiveness, and Achievement have statistically significantly higher average values for employees than for students. Students have statistically significantly higher average values of the following dimensions: Personal attitude, Subjective norm, and Entrepreneurial intention. Dimensions Innovativeness and Perceived behavioural control are equally present in both students and employees. 2. Results for female students and female employees show identical results as for the total sample. Results for male students and male employees differentiate in that the male employees' attitudes toward entrepreneurship remain high even though they have a job. 3. The highest values for Personal attitude and Entrepreneurial intention dimensions are achieved by male students, and thereafter by female students, male employees, and the lowest by female employees. 4. The minimum difference between entrepreneurial attitudes and intentions is among male students, whereas the maximum difference between entrepreneurial attitudes and intentions emerge with male employees.
\end{abstract}

Keywords: Individual entrepreneurial orientation; Achievement; Theory of planned behaviour; Students; Employees; Gender; Serbia.

\section{INTRODUCTION}

Entrepreneurship is of great economic and social importance. Many authors point out this fact, for example (Brandstätter, 2011; Muzychenko, 2008). According to (Hisrich, Langan-Fox, \& Grant, 2007), entrepreneurship is a major source of employment, economic growth, innovation, competition, and economic flexibility in contemporary society. Similarly, Obschonka and Stuetzer (2017) indicate that entrepreneurship is a major source of employment, economic growth, and technological progress. Also, entrepreneurship contributes not only to job creation and economic growth, increases productivity and competitiveness, but encourages companies to innovate and act effectively (Mortan, Ripoll, Carvalho, \& Bernal, 2014). Finally, entrepreneurship creates wealth and affects unemployment (Paul, \& Shrivatava, 2016). According to Sajfert and Ćočkalo, (2018), entrepreneurship has four significant benefits: innovation, economic growth, job opportunities, and career opportunities for women and minorities. 
There is no doubt that this is the moment for entrepreneurship, and entrepreneurship itself and its concepts are widely accepted by educational institutions, state institutions, government units, organizations, and also the society as a whole (Hisrich, Peters, \& Shepherd, 2008).

Bearing all this in mind, entrepreneurship is catching the attention of researchers around the world. There are numerous studies related to determining the conditions, reasons, causes, personal traits, and various environmental influences, necessary and desirable for an individual to obtain entrepreneurial intentions, which would later lead to entrepreneurial behaviour. In this sense, the effects of different variables on the emergence of entrepreneurial intentions and entrepreneurship in general are often examined. Among other things, the effects of variables such as Big Five personal traits, individual entrepreneurial orientation dimensions, achievement dimension, the theory of planned behavioural dimensions, gender, the existence of an entrepreneurial tradition in the family, age, possession of finances to start one's own business are examined.

Entrepreneurship is a process, it cannot happen instantaneously or in a short period of time. This process must be preceded by an individual's intention to become an entrepreneur. Understanding entrepreneurial intentions is very important for easier and more efficient identification and encouragement of people who have such intentions. Generally, a stronger intention for some behavior and activity increases the degree of likelihood of realization and realization of a given intention. Accordingly, stronger entrepreneurial intention undoubtedly strengthens the likelihood of starting an entrepreneurial venture (Ajzen, 1991). Therefore, this topic (entrepreneurial intentions) is a frequent subject of research in the field of entrepreneurship, and it looks like it will be in the future.

In entrepreneurial intentions surveys, respondents are most often students, in $65 \%$ of such surveys (Schlaegel, \& Koenig, 2014). Such studies are, for example (Kwong, \& Thompson, 2016; Shinnar, Giacomin, \& Janssen, 2012; Tkachev, \& Kolvereid, 1999; Altinay, Madanoglu, Daniele, \& Lashley, 2012; Lüthje, \& Franke, 2003; Siu, \& Lo, 2013).

On the other hand, research on entrepreneurial intentions among employed persons is not as prevalent. Some references, however, relate to this topic, for example (Hatak, Harms, \& Fink, 2015; Hsu, Shinnar, Powell, \& Coffey, 2017; Hyytinen, \& Ilmakunnas, 2007). Also, some research considers intentions to leave the organization, but without the existence of entrepreneurial intentions (Kickul, 2001; Monsen, \& Boss, 2009; Rafferty, \& Griffin, 2006).

This paper focuses on the comparison of entrepreneurial intentions among students in Serbia and employees of organizations in Serbia. More specifically, a comparison of individual entrepreneurial orientation dimensions, achievement dimension, and theory of planned behavior dimensions (including entrepreneurship intention dimension) is made with students and employees in Serbia. In doing so, the paper uses a sample of two previous studies: a study of entrepreneurial intentions by students in Serbia (Rajković, Nikolić, Ćoćkalo, Terek, \& Božić, 2020), and an exploration of entrepreneurial intentions by employed persons in Serbia (Mali, Kuzmanović, Nikolić, Mitić, \& Terek, 2019). Common to the two surveys is that the dimensions mentioned above have been examined, so a comparison is now possible for the two observed groups (students and employees). Comparison is also made with respect to the control variable: gender of subjects. Thus, comparisons of observed dimensions were made both among female students and female employees and among male students and male employees.

This research and analysis of the obtained results have a strong theoretical significance for the field of entrepreneurial intentions, especially since the entrepreneurial intentions of students and employees have not been sufficiently analyzed in this way so far. Also, research has practical value, in terms of identifying and defining opportunities for targeting state institutions, whose task is to encourage and develop entrepreneurship.

\section{THEORY AND HYPOTHESIS}

\section{Entrepreneurial intentions in college students}

According to Espiritu-Olmos, and Sastre-Castillo, (2015), personal traits have a greater influence on entrepreneurial intentions than work values. Similarly, for students at the MIT School of Engineering, personal traits have a strong influence on the attitude toward starting their own business (Lüthje, \& Franke, 2003). Also, the entrepreneurial 
intentions of these students are influenced by perceived barriers as well as perceived support factors from the environment. A survey among UK students (Altinay, Madanoglu, Daniele, \& Lashley, 2012) found that innovation and entrepreneurial intentions can be driven by the existence of entrepreneurial activities in the family.

Some research considers the influence of national culture on entrepreneurship, from the perspective of students, for example (Adekiya, \& Ibrahim, 2016; Mueller, \& Thomas, 2001; Naktiyok, Karabey, \& Gulluce, 2010). Some studies point to the importance of institutional and social support. For students in Croatia, personal, situational, educational, and social factors have a direct influence on entrepreneurial intentions (Pfeifer, Šarlija, \& Zekić Sušac, 2016). In South Africa, for the development of students' entrepreneurial intentions, it is important that students are supported by the government and appropriate state institutions (Malebana, 2017).

\section{Entrepreneurial intentions in employees}

A survey of entrepreneurial intentions in current employees in Australia (Hatak, Harms, \& Fink, 2015) found that entrepreneurial intentions are declining in older employees, and that entrepreneurial intentions are lower in employees who are more identified with their job. Also, gender, education, and previous entrepreneurial experience have an impact on entrepreneurial intentions, while this cannot be said for leadership and having entrepreneurial parents. According to Hsu, Shinnar, Powell, and Coffey, (2017) with employees of existing organizations, entrepreneurial intentions are strengthened in the event of adverse organizational climate, adverse organizational structure, and inadequate corporate entrepreneurial orientation of the organization.

According to Sajfert and Ćoćkalo (2018), strong dissatisfaction with the job or the work environment forces the individual to think about starting their own business. Accordingly, Hyytinen and Ilmakunnas (2007) show that entrepreneurial aspirations and desire to switch jobs usually occur simultaneously. Also, these employee's aspirations are heightened under conditions where job dissatisfaction and discontent with their superiors is present. Some other studies are about intentions to quit an existing job without considering whether these individuals want to start an entrepreneurial venture, for example (Kickul, 2001; Monsen, \& Boss, 2009; Rafferty, \& Griffin, 2006).
In this paper, three hypotheses are put forward:

H1: There is a statistically significant difference in the average values of individual entrepreneurial orientation dimensions, achievement dimension, and theory of planned behaviour dimensions, among students and employees.

$\mathrm{H} 2$ : There is a statistically significant difference in the average values of individual entrepreneurial orientation dimensions, achievement dimension, and theory of planned behaviour dimensions, among female students and female employees.

H3: There is a statistically significant difference in the average values of individual entrepreneurial orientation dimensions, achievement dimension, and theory of planned behaviour dimensions, among male students and male employees.

\section{METHOD}

\section{Survey instruments}

The Individual Entrepreneurial Orientation (IEO) instrument was used to measure individual entrepreneurial orientation (Bolton, \& Lane, 2012). The questionnaire has 10 items and 3 dimensions: 1. Risk-taking, 2. Innovativeness and 3. Proactiveness.

The need for achievement was measured via the Achievement dimension of the Attitude Toward Enterprise (ATE) Test instrument (Athayde, 2009). This dimension has 4 items.

The Entrepreneurial Intention Questionnaire (EIQ) was used to measure the dimensions of The Theory of Planned Behaviour (Liñán, \& Chen, 2009). The questionnaire has 20 items and 4 dimensions: 1 . Personal attitude, 2. Subjective norm, 3. Perceived behavioural control and 4. Entrepreneurial intention.

All three questionnaires were used in both surveys: a survey of entrepreneurial intentions by students in Serbia (Rajković, Nikolić, Ćoćkalo, Terek, \& Božić, 2020), and a survey of entrepreneurial intentions by employed persons in Serbia (Mali, Kuzmanović, Nikolić, Mitić, \& Terek, 2019). Also, all three questionnaires are graded on a seven-point Likert scale.

\section{Participants}

The survey among students was conducted through an anonymous survey. The respondents were 
students from seven faculties in Serbia. These are faculties of technical and economic orientation. 488 valid questionnaires were collected. 337 (69.1\%) female students and 151 (30.9\%) male students were sampled.

The survey among employees was conducted through an anonymous survey. The respondents were employees of the organizations in Serbia. Medium and large enterprises are included size wise, and by type of activity, production, service, and public companies are included. 540 valid questionnaires were collected. The sample was 255 (47.2\%) female and 285 (52.8\%) male.

For the purposes of this research, two databases are listed in the database, in the part related to the observed dimensions (entrepreneurial orientation dimensions, achievement dimension, and the theory of planned behavioural dimensions). The structure of the total sample (sample containing data from both research) is shown in Table 1.

\section{RESULTS}

\section{Descriptive statistics}

Descriptive statistics for individual entrepreneurial orientation dimensions, achievement dimension, and the theory of planned behaviour dimensions are shown in Table 2. This table gives the names of dimensions with abbreviations, then mean values, standard deviation, and Cronbach's alpha for each dimension. Cronbach's alpha values take values from 0.787 to 0.947 . The results in Table 2 relate to the total sample.

\section{Analysis via t-test}

A t-test was used to compare average scores of individual entrepreneurial orientation dimensions, achievement dimension, and theory of planned behaviour dimensions. The results of the t-test are presented in three Tables (Table 3, Table 4, and Table 5). In these tables, the average dimensions for which there is a statistically significant difference are shown in bold font.

The results of the t-test over the average grades of individual entrepreneurial orientation dimensions, achievement dimension, and theory of planned behaviour dimensions, for students and employees, are given in Table 3.

The results of the t-test over the average scores of individual entrepreneurial orientation dimensions, achievement dimension, and theory of planned behaviour dimensions, for female students and female employees, are given in Table 4.

The results of the t-test over the average grades of individual entrepreneurial orientation dimensions, achievement dimension, and theory of planned behaviour dimensions, for male students and male employees, are given in Table 5.

Table 1: Structure of the total sample

\begin{tabular}{|c|c|c|c|c|c|}
\hline \multicolumn{2}{|c|}{ Total sample } & \multicolumn{2}{c|}{ Total sample } & \multicolumn{2}{c|}{ Total sample } \\
\hline Student & $488(47.5 \%)$ & Female & $592(57.6 \%)$ & Female students & $337(32.8 \%)$ \\
\hline Employees & $540(52.5 \%)$ & Male & $436(42.4 \%)$ & Female employees & $255(24.8 \%)$ \\
\hline & & & & Male students & $151(14.7 \%)$ \\
\cline { 5 - 6 } & & & & Male employees & $285(27.7 \%)$ \\
\hline Total & $1028(100 \%)$ & & $1028(100 \%)$ & & $1028(100 \%)$ \\
\hline
\end{tabular}

Table 2: Descriptive statistics for the total sample (individual entrepreneurial orientation dimensions, achievement dimension, and the theory of planned behaviour dimensions)

\begin{tabular}{|l|c|c|c|c|c|c|}
\hline \multicolumn{1}{|c|}{ Dimensions with abbreviations } & $\mathrm{N}$ & Min & Max & Mean & Std. Dev. & $\begin{array}{c}\text { Cronbach's } \\
\text { Alpha }\end{array}$ \\
\hline RT - Risk-taking & 1028 & 1.000 & 7.000 & 4.39040 & 1.434715 & 0.787 \\
\hline IN - Innovativeness & 1028 & 1.000 & 7.000 & 4.86625 & 1.231972 & 0.826 \\
\hline PR - Proactiveness & 1028 & 1.000 & 7.000 & 5.39721 & 1.238219 & 0.822 \\
\hline ACH - Achievement & 1028 & 1.000 & 7.000 & 4.75973 & 1.314301 & 0.858 \\
\hline PA - Personal attitude & 1028 & 1.000 & 7.000 & 4.67218 & 1.338794 & 0.885 \\
\hline SN - Subjective norm & 1028 & 1.000 & 7.000 & 5.32263 & 1.306611 & 0.829 \\
\hline PBC - Perceived behavioural control & 1028 & 1.000 & 7.000 & 4.19001 & 1.263549 & 0.895 \\
\hline EI - Entrepreneurial intention & 1028 & 1.000 & 7.000 & 3.54150 & 1.573562 & 0.947 \\
\hline \multicolumn{1}{|c|}{ Valid N (list wise) } & 1028 & & & & & \\
\hline
\end{tabular}


Table 3: T-test over average scores individual entrepreneurial orientation dimensions, achievement dimension and the theory of planned behavior dimensions, for students and employees

\begin{tabular}{|c|c|c|c|c|c|}
\hline \multicolumn{6}{|c|}{ Group Statistics } \\
\hline & $\begin{array}{l}\text { Stud. / } \\
\text { Empl. }\end{array}$ & $\mathrm{N}$ & Mean & $\begin{array}{c}\text { Std. } \\
\text { Deviation }\end{array}$ & $\begin{array}{l}\text { Std. Error } \\
\text { Mean }\end{array}$ \\
\hline \multirow{2}{*}{ RT } & 1 Stud. & 488 & 4.16325 & 1.334868 & .060427 \\
\hline & 2 Empl. & 540 & 4.59568 & 1.491024 & .064163 \\
\hline \multirow{2}{*}{ IN } & 1 Stud. & 488 & 4.86373 & 1.141717 & .051683 \\
\hline & 2 Empl. & 540 & 4.86852 & 1.309247 & .056341 \\
\hline \multirow{2}{*}{ PR } & 1 Stud. & 488 & 4.98497 & 1.216943 & .055088 \\
\hline & 2 Empl. & 540 & 5.76975 & 1.135924 & .048882 \\
\hline \multirow{2}{*}{$\mathbf{A C H}$} & 1 Stud. & 488 & 4.25410 & 1.259047 & .056994 \\
\hline & 2 Empl. & 540 & 5.21667 & 1.190972 & .051251 \\
\hline \multirow{2}{*}{ PA } & 1 Stud. & 488 & 4.80410 & 1.231543 & .055749 \\
\hline & 2 Empl. & 540 & 4.55667 & 1.419594 & .060849 \\
\hline \multirow{2}{*}{ SN } & 1 Stud. & 488 & 5.59563 & 1.247570 & .056475 \\
\hline & 2 Empl. & 540 & 5.07407 & 1.309199 & .056382 \\
\hline \multirow{2}{*}{$\mathrm{PBC}$} & 1 Stud. & 488 & 4.14139 & 1.189466 & .053845 \\
\hline & 2 Empl. & 540 & 4.23395 & 1.326513 & .057084 \\
\hline \multirow{2}{*}{ EI } & 1 Stud. & 488 & 3.78279 & 1.486135 & .067274 \\
\hline & 2 Empl. & 540 & 3.32346 & 1.619272 & .069682 \\
\hline
\end{tabular}

Table 3: Continuation

\begin{tabular}{|c|c|c|c|c|c|c|c|c|}
\hline \multicolumn{9}{|c|}{ Independent Samples Test } \\
\hline & \multirow{2}{*}{$\begin{array}{l}\text { Stud. / } \\
\text { Empl. }\end{array}$} & \multicolumn{2}{|c|}{$\begin{array}{c}\text { Levene's Test for } \\
\text { Equality of Variances }\end{array}$} & \multicolumn{5}{|c|}{ t-test for Equality of Means } \\
\hline & & $\mathrm{F}$ & Sig. & $\mathrm{t}$ & df & $\begin{array}{c}\text { Sig. } \\
\text { (2-tailed) }\end{array}$ & $\begin{array}{c}\text { Mean } \\
\text { Difference }\end{array}$ & $\begin{array}{l}\text { Std. Error } \\
\text { Difference }\end{array}$ \\
\hline \multirow{2}{*}{$\mathbf{R T}$} & 1 Stud. & \multirow[t]{2}{*}{8.633} & \multirow[t]{2}{*}{.003} & -4.879 & 1026 & .000 & -.432428 & .088631 \\
\hline & 2 Empl. & & & -4.906 & $\mathbf{1 0 2 5 . 9 1 2}$ & .000 & -.432428 & .088138 \\
\hline \multirow{2}{*}{ IN } & 1 Stud. & \multirow[t]{2}{*}{5.558} & \multirow[t]{2}{*}{.019} & -.062 & 1026 & .950 & -.004789 & .076984 \\
\hline & 2 Empl. & & & -.063 & 1024.713 & .950 & -.004789 & .076456 \\
\hline \multirow{2}{*}{ PR } & 1 Stud. & \multirow[t]{2}{*}{4.154} & \multirow[t]{2}{*}{.042} & -10.693 & 1026 & .000 & -.784780 & .073393 \\
\hline & 2 Empl. & & & -10.656 & 997.228 & .000 & -.784780 & .073649 \\
\hline \multirow{2}{*}{ ACH } & 1 Stud. & \multirow[t]{2}{*}{.006} & \multirow[t]{2}{*}{.936} & -12.594 & 1026 & .000 & -.962568 & .076434 \\
\hline & 2 Empl. & & & -12.558 & 1001.411 & .000 & -.962568 & .076649 \\
\hline \multirow{2}{*}{$\mathbf{P A}$} & 1 Stud. & \multirow[t]{2}{*}{5.618} & \multirow[t]{2}{*}{.018} & 2.977 & 1026 & .003 & .247432 & .083102 \\
\hline & 2 Empl. & & & 2.998 & 1024.622 & .003 & .247432 & .082526 \\
\hline \multirow{2}{*}{$\mathbf{S N}$} & 1 Stud. & \multirow[t]{2}{*}{.248} & \multirow[t]{2}{*}{.618} & 6.519 & 1026 & .000 & .521554 & .080000 \\
\hline & 2 Empl. & & & 6.536 & 1023.191 & .000 & .521554 & .079802 \\
\hline \multirow{2}{*}{ PBC } & 1 Stud. & \multirow[t]{2}{*}{5.293} & \multirow[t]{2}{*}{.022} & -1.173 & 1026 & .241 & -.092557 & .078905 \\
\hline & 2 Empl. & & & -1.179 & 1025.939 & .238 & -.092557 & .078472 \\
\hline \multirow{2}{*}{ EI } & 1 Stud. & \multirow[t]{2}{*}{9.303} & \multirow[t]{2}{*}{.002} & 4.722 & 1026 & .000 & .459330 & .097279 \\
\hline & 2 Empl. & & & 4.742 & 1025.752 & .000 & .459330 & .096858 \\
\hline
\end{tabular}


Table 4: T-test over average scores individual entrepreneurial orientation dimensions, achievement dimension and the theory of planned behaviour dimensions, for female students and female employees

\begin{tabular}{|c|c|c|c|c|c|}
\hline \multicolumn{6}{|c|}{ Group Statistics } \\
\hline & $\begin{array}{l}\text { Fem. St. / } \\
\text { Fem Em. }\end{array}$ & $\mathrm{N}$ & Mean & $\begin{array}{c}\text { Std. } \\
\text { Deviation }\end{array}$ & $\begin{array}{l}\text { Std. Error } \\
\text { Mean }\end{array}$ \\
\hline \multirow{2}{*}{ RT } & Fem. St. & 337 & 4.11672 & 1.366488 & .074437 \\
\hline & Fem. Em. & 255 & 4.53856 & 1.518958 & .095121 \\
\hline \multirow{2}{*}{ IN } & Fem. St. & 337 & 4.88501 & 1.147891 & .062530 \\
\hline & Fem. Em. & 255 & 4.86863 & 1.357538 & .085012 \\
\hline \multirow{2}{*}{ PR } & Fem. St. & 337 & 5.05440 & 1.213627 & .066110 \\
\hline & Fem. Em. & 255 & 5.73072 & 1.125460 & .070479 \\
\hline \multirow{2}{*}{ ACH } & Fem. St. & 337 & 4.24926 & 1.313350 & .071543 \\
\hline & Fem. Em. & 255 & 5.15098 & 1.220014 & .076400 \\
\hline \multirow{2}{*}{ PA } & Fem. St. & 337 & 4.76499 & 1.222248 & .066580 \\
\hline & Fem. Em. & 255 & 4.32863 & 1.428866 & .089479 \\
\hline \multirow{2}{*}{$\mathbf{S N}$} & Fem. St. & 337 & 5.69436 & 1.192691 & .064970 \\
\hline & Fem. Em. & 255 & 5.04837 & 1.319089 & .082605 \\
\hline \multirow{2}{*}{ PBC } & Fem. St. & 337 & 4.07072 & 1.221714 & .066551 \\
\hline & Fem. Em. & 255 & 4.10719 & 1.338921 & .083846 \\
\hline \multirow{2}{*}{ EI } & Fem. St. & 337 & 3.64688 & 1.525230 & .083085 \\
\hline & Fem. Em. & 255 & 3.15098 & 1.670001 & .104580 \\
\hline
\end{tabular}

Table 4: Continuation

\begin{tabular}{|c|c|c|c|c|c|c|c|c|}
\hline \multicolumn{9}{|c|}{ Independent Samples Test } \\
\hline & \multirow{2}{*}{$\begin{array}{l}\text { Fem. St. / } \\
\text { Fem Em. }\end{array}$} & \multicolumn{2}{|c|}{$\begin{array}{l}\text { Levene's Test for } \\
\text { Equality of Variances }\end{array}$} & \multicolumn{5}{|c|}{ t-test for Equality of Means } \\
\hline & & $\mathrm{F}$ & Sig. & $\mathrm{t}$ & df & $\begin{array}{c}\text { Sig. } \\
\text { (2-tailed) }\end{array}$ & $\begin{array}{c}\text { Mean } \\
\text { Difference }\end{array}$ & $\begin{array}{l}\text { Std. Error } \\
\text { Difference }\end{array}$ \\
\hline \multirow{2}{*}{ RT } & Fem. St. & \multirow[t]{2}{*}{4.140} & \multirow[t]{2}{*}{.042} & -3.544 & 590 & .000 & -.421846 & .119031 \\
\hline & Fem. Em. & & & -3.493 & 514.493 & .001 & -.421846 & .120784 \\
\hline \multirow{2}{*}{ IN } & Fem. St. & \multirow[t]{2}{*}{4.984} & \multirow[t]{2}{*}{.026} & .159 & 590 & .874 & .016387 & .103126 \\
\hline & Fem. Em. & & & .155 & 493.898 & .877 & .016387 & .105532 \\
\hline \multirow{2}{*}{ PR } & Fem. St. & \multirow[t]{2}{*}{1.975} & \multirow[t]{2}{*}{.160} & -6.926 & 590 & .000 & -.676317 & .097647 \\
\hline & Fem. Em. & & & -6.999 & 566.234 & .000 &.- .676317 & .096633 \\
\hline \multirow{2}{*}{ ACH } & Fem. St. & \multirow[t]{2}{*}{.050} & \multirow[t]{2}{*}{.824} & -8.528 & 590 & .000 & -.901722 & .105742 \\
\hline & \begin{tabular}{|l} 
Fem. Em. \\
\end{tabular} & & & -8.615 & 565.851 & .000 & -.901722 & .104668 \\
\hline \multirow{2}{*}{ PA } & \begin{tabular}{|l} 
Fem. St. \\
\end{tabular} & \multirow[t]{2}{*}{4.624} & \multirow[t]{2}{*}{.032} & 4.002 & 590 & .000 & .436358 & .109040 \\
\hline & Fem. Em. & & & 3.918 & 498.498 & .000 & .436358 & .111377 \\
\hline \multirow{2}{*}{ SN } & Fem. St. & \multirow[t]{2}{*}{2.381} & \multirow[t]{2}{*}{.123} & 6.233 & 590 & .000 & .645996 & .103640 \\
\hline & Fem. Em. & & & 6.147 & 516.142 & .000 & .645996 & .105093 \\
\hline \multirow{2}{*}{$\mathrm{PBC}$} & Fem. St. & \multirow[t]{2}{*}{1.877} & \multirow[t]{2}{*}{.171} & -.345 & 590 & .730 & -.036467 & .105700 \\
\hline & \begin{tabular}{|l} 
Fem. Em. \\
\end{tabular} & & & -.341 & 519.102 & .733 & -.036467 & .107048 \\
\hline \multirow{2}{*}{ EI } & Fem. St. & \multirow[t]{2}{*}{7.170} & \multirow[t]{2}{*}{.008} & 3.760 & 590 & .000 & .495904 & .131901 \\
\hline & \begin{tabular}{|l} 
Fem. Em. \\
\end{tabular} & & & 3.713 & 519.403 & .000 & .495904 & .133566 \\
\hline
\end{tabular}


Table 5: T-test over average scores individual entrepreneurial orientation dimensions, achievement dimension and the theory of planned behaviour dimensions, for male students and male employees

\begin{tabular}{|c|c|c|c|c|c|}
\hline \multicolumn{6}{|c|}{ Group Statistics } \\
\hline & $\begin{array}{l}\text { Male St. / } \\
\text { Male Em. }\end{array}$ & $\mathrm{N}$ & Mean & $\begin{array}{c}\text { Std. } \\
\text { Deviation }\end{array}$ & $\begin{array}{l}\text { Std. Error } \\
\text { Mean }\end{array}$ \\
\hline \multirow{2}{*}{ RT } & Male St. & 151 & 4.26711 & 1.259641 & .102508 \\
\hline & Male Em. & 285 & 4.64678 & 1.466366 & .086860 \\
\hline \multirow{2}{*}{ IN } & Male St. & 151 & 4.81623 & 1.130156 & .091971 \\
\hline & Male Em. & 285 & 4.86842 & 1.266880 & .075044 \\
\hline \multirow{2}{*}{ PR } & Male St. & 151 & 4.83002 & 1.214034 & .098797 \\
\hline & Male Em. & 285 & 5.80468 & 1.146053 & .067886 \\
\hline \multirow{2}{*}{$\mathbf{A C H}$} & Male St. & 151 & 4.26490 & 1.132560 & .092166 \\
\hline & Male Em. & 285 & 5.27544 & 1.163376 & .068912 \\
\hline \multirow{2}{*}{ PA } & Male St. & 151 & 4.89139 & 1.251716 & .101863 \\
\hline & Male Em. & 285 & 4.76070 & 1.383250 & .081937 \\
\hline \multirow{2}{*}{ SN } & Male St. & 151 & 5.37528 & 1.340152 & .109060 \\
\hline & Male Em. & 285 & 5.09708 & 1.301382 & .077087 \\
\hline \multirow{2}{*}{$\mathrm{PBC}$} & Male St. & 151 & 4.29912 & 1.101736 & .089658 \\
\hline & Male Em. & 285 & 4.34737 & 1.307256 & .077435 \\
\hline \multirow{2}{*}{ EI } & Male St. & 151 & 4.08609 & 1.351111 & .109952 \\
\hline & Male Em. & 285 & 3.47778 & 1.559304 & .092365 \\
\hline
\end{tabular}

Table 5: Continuation

\begin{tabular}{|c|c|c|c|c|c|c|c|c|}
\hline \multicolumn{9}{|c|}{ Independent Samples Test } \\
\hline & \multirow{2}{*}{$\begin{array}{l}\text { Male St. / } \\
\text { Male Em. }\end{array}$} & \multicolumn{2}{|c|}{$\begin{array}{l}\text { Levene's Test for } \\
\text { Equality of Variances }\end{array}$} & \multicolumn{5}{|c|}{ t-test for Equality of Means } \\
\hline & & $\mathrm{F}$ & Sig. & $\mathrm{t}$ & df & $\begin{array}{c}\text { Sig. } \\
\text { (2-tailed) }\end{array}$ & $\begin{array}{c}\text { Mean } \\
\text { Difference }\end{array}$ & $\begin{array}{l}\text { Std. Error } \\
\text { Difference }\end{array}$ \\
\hline \multirow{2}{*}{ RT } & Male St. & \multirow[t]{2}{*}{5.997} & \multirow[t]{2}{*}{.015} & -2.697 & 434 & .007 & -.379675 & .140753 \\
\hline & Male Em. & & & -2.826 & 347.979 & .005 & -.379675 & 134360 \\
\hline \multirow{2}{*}{ IN } & Male St. & \multirow[t]{2}{*}{1.740} & \multirow[t]{2}{*}{.188} & -.425 & 434 & .671 & -.052196 & .122935 \\
\hline & Male Em. & & & -.440 & 337.263 & .660 & -.052196 & 118702 \\
\hline \multirow{2}{*}{ PR } & Male St. & \multirow[t]{2}{*}{2.004} & \multirow[t]{2}{*}{.158} & -8.276 & 434 & .000 & -.974656 & .117765 \\
\hline & Male Em. & & & -8.131 & 290.840 & .000 & -.974656 & .119872 \\
\hline \multirow{2}{*}{ ACH } & Male St. & \multirow[t]{2}{*}{1.035} & \multirow[t]{2}{*}{.310} & -8.709 & 434 & .000 & -1.010538 & .116036 \\
\hline & Male Em. & & & -8.781 & 312.938 & .000 & -1.010538 & 115081 \\
\hline \multirow{2}{*}{ PA } & Male St. & \multirow[t]{2}{*}{271} & \multirow[t]{2}{*}{.603} & .974 & 434 & .331 & .130689 & .134176 \\
\hline & Male Em. & & & 1.002 & 331.343 & .317 & 130689 & 130387 \\
\hline \multirow{2}{*}{ SN } & Male St. & \multirow[t]{2}{*}{1.733} & \multirow[t]{2}{*}{.189} & 2.099 & 434 & .036 & .278200 & 132528 \\
\hline & Male Em. & & & 2.082 & 298.570 & .038 & .278200 & 133646 \\
\hline \multirow{2}{*}{ PBC } & Male St. & \multirow[t]{2}{*}{3.611} & \multirow[t]{2}{*}{.058} & -.387 & 434 & .699 & -.048251 & 124820 \\
\hline & Male Em. & & & -.407 & 353.388 & .684 & -.048251 & .118468 \\
\hline \multirow{2}{*}{ EI } & Male St. & \multirow[t]{2}{*}{6.861} & \multirow[t]{2}{*}{.009} & 4.054 & 434 & .000 & .608315 & .150039 \\
\hline & Male Em. & & & 4.236 & 345.524 & .000 & .608315 & 143599 \\
\hline
\end{tabular}

\section{DISCUSSION}

\section{Discussion of the results of t-test for students and employees}

The results of the t-test for students and employees (Table 3) show that, for employed persons, the dimensions RT - Risk-taking, PR - Proactiveness, and $\mathrm{ACH}$ - Achievement have statistically significantly higher average values than for students. These dimensions, and in particular RT Risk-taking, are more pronounced in employees because of security, which stems from the fact that they have a job and, therefore, regular financial income. Also, employees have strong and realistic opportunities but also a need for advancement. Such opportunities, as well as responsibilities that arise at work, make employees more likely to plan 
and think about future activities and consequently have a greater proactive attitude.

On the other hand, students have statistically significantly higher average values of the following dimensions: PA - Personal attitude, SN Subjective norm, and EI - Entrepreneurial intention. This can easily be explained by the fact that employed persons already have a job and thus less need for entrepreneurship. Students are (predominantly) not employed and they, in their thinking about starting their business venture, have no restrictions on the type of existing job, in terms of current responsibilities, but also in the security provided by that job. As a result, students have more positive attitude towards entrepreneurship, as well as firmer intentions to start a business. These circumstances are likely recognized by the environment, so students are more supported in entrepreneurial thinking (attitudes and intentions) by family, friends, and colleagues (higher average value of the dimension SN - Subjective norm). Employees have the impression that their job provides them with security and increases their willingness to take risks, but at the same time, this job diminishes their entrepreneurial attitudes and intentions.

It should be noted that dimensions IN Innovativeness and PBC - Perceived behavioural control are equally present in students and employees. From aforementioned, it can be concluded that the perception of one's own innovativeness and ability depends not so much on whether a person is studying or having a job, but on how that person perceives him/herself. Given that most of the observed dimensions have statistically significant differences in the height of average grades (according to the t-test for students and employees), it can be stated that Hypothesis $\mathrm{H} 1$ is confirmed.

\section{Discussion of the results of t-test for female students and female employees}

The results of the t-test for female students and female employees (Table 4) show identical results as the t-test for the total sample. Thus, for female employees, the dimensions RT - Risk-taking, PR Proactiveness, and ACH - Achievement have statistically significantly higher average values than for female students. At the same time, statistically significantly higher mean values of the following dimensions occur in female students: PA - Personal attitude, SN - Subjective norm, and EI -
Entrepreneurial intention. Similarly, dimensions IN - Innovativeness and PBC - Perceived behavioural control are equally present in female students and female employees.

Given the identity of the results, the discussions and justifications given for the total sample are valid in this case as well. Since statistically significant differences in the average grades (according to the t-test for female students and female employees) occur in most of the observed dimensions, it can be stated that Hypothesis $\mathrm{H} 2$ is confirmed.

\section{Discussion of the results of t-test for male students and male employees}

The results of the t-test for male students and male employees (Table 5) show similar results to the ttest for the total sample and the t-test for female students and female employees. For male employees, the RT - Risk-taking, PR Proactiveness, and ACH - Achievement dimensions have statistically significantly higher average values than for male students. Furthermore, statistically significantly higher average values of the following dimensions occur in male students: SN - Subjective norm and EI Entrepreneurial intention. In such cases, the explanations given above apply.

What differs previous two analyses is that there is no statistically significant difference in the average values for dimension PA - Personal attitude. For male employees, attitudes toward entrepreneurship remain high, regardless of what they do. This leads to the conclusion that men often fantasize about the business entrepreneurship and that they wish for such opportunity, even though they have a job. For them, owning your own business is an opportunity to gain desirable freedom and independence.

Although there is no statistically significant difference in the average values for dimension PA - Personal attitude, in most of the observed dimensions, statistically significant differences in the height of average grades still occur (according to the t-test for small students and small employees). Therefore, it can be concluded that Hypothesis H3 is confirmed. 


\section{Discussion of the results for personal attitude and entrepreneurial intention}

It is useful to consider the average grades of each dimension for the observed four groups of respondents: female students, female employees, male students, and male employees. First of all, this relates to two, probably the most significant dimensions: PA - Personal attitude and EI Entrepreneurial intention. In these two dimensions, male students achieved the highest values, subsequently female students, male employees, whereas the lowest was achieved by female employees. Thus, the strongest entrepreneurial attitudes and intentions are among male students and the weakest among female employees. This is especially outlined for entrepreneurial intentions. Young students mostly think about the entrepreneurial vocation and have the strongest intentions to do so. Such results are in line with most previous research when it comes to entrepreneurial intentions of young students i.e. female students (do Paço, Matos Ferreira, Raposo, Gouveia Rodrigues, \& Dinis, 2015; Santos, Roomi, \& Liñán, 2016; Shneor, Metin Camgöz, \& Bayhan Karapinar, 2013), but also with studies that indicate generally stronger entrepreneurial intentions in men than women (Leppel, 2016; Santos, Roomi, \& Liñán, 2016; Shneor, Metin Camgöz, \& Bayhan Karapinar, 2013).

It should also be noted the least difference for male students is between entrepreneurial attitudes and intentions. Conversely, the biggest differences between entrepreneurial attitudes and intentions occur with male employees. Male students are mostly determined and resolute to materialize positive entrepreneurial attitudes by starting their own entrepreneurial ventures. Male employees have a strong sympathy for owning their own business, but also have low intentions to actually see it through. The result for male employees is consistent with the high average rating for dimension PA - Personal attitude, in this group of respondents, as discussed previously.

\section{CONCLUSION}

Dimensions RT - Risk-taking, PR - Proactiveness, and $\mathrm{ACH}$ - Achievement have statistically significantly higher average values in employed persons than in students. Students have statistically significantly higher average values of the following dimensions: PA - Personal attitude, SN Subjective norm, and EI - Entrepreneurial intention. Dimensions IN - Innovativeness and PBC - Perceived behavioural control is equally present in both students and employees.

The results of the t-test for female students and female employees show identical results as the ttest for the total sample. Results of the t-test for male students and male employees show similar results to the t-test for the total sample and the $\mathrm{t}$ test for female students and female employees, with one difference: there is no statistically significant difference in the average values for dimension PA - Personal attitude. For male employees, attitudes toward entrepreneurship remain high, they often fantasize about the entrepreneur's job and hope for such an opportunity, even though they have a job. The smallest differences between entrepreneurial attitudes and intentions exist with male students, accordingly the largest differences between entrepreneurial attitudes and intentions occur with male employees.

Male students acquired the highest values of Dimensions PA - Personal attitude and EI Entrepreneurial intention, followed by female students, male employees, and lowest by female employees. Thus, male students have the strongest entrepreneurial attitudes and intentions whereas female employees have the weakest. This is especially susceptible for entrepreneurial intentions.

The paper is of theoretical importance because it deals with the comparison of entrepreneurial attitudes and intentions among students and employees, which has not been sufficiently researched so far. The outcome resulting from the introduction into the analysis of the control variable of the respondents' gender, provides additional theoretical value to the research.

In practical terms, the importance of the work is that it indicates a greater propensity for entrepreneurship among students than among employees and especially students. Students should be systematically encouraged for entrepreneurship, by reinforcing the need for achievement and being proactive. However, it is paramount that students, who show a propensity for entrepreneurship, are given appropriate financial assistance and incentives to increase their risk-taking readiness. At the same time, in an entrepreneurial sense, employees should not be neglected either: they possess some of the necessary entrepreneurial 
predispositions, such as the increased need for achievement, proactiveness, and willingness to take risks. As a result, state institutions involved in promoting and developing entrepreneurship should also encourage employed persons to become entrepreneurs.

\section{REFERENCES}

Adekiya, A.A., Ibrahim, F. (2016). Entrepreneurship intention among students. The antecedent role of culture and entrepreneurship training and development. The International Journal of Management Education, 14(2), 116-132. doi:10.1016/j.ijme.2016.03.001

Ajzen, I. (1991). Theory of planned behavior. Organizational Behavior and Human Decision Processes, 50(2), 179-211.

Altinay, L., Madanoglu, M., Daniele, R., Lashley, C. (2012). The influence of family tradition and psychological traits on entrepreneurial intention. International Journal of Hospitality Management, 31(2), 489-499. doi:10.1016/j.ijhm.2011.07.007

Athayde, R. (2009). Measuring Enterprise Potential in Young People. Entrepreneurship Theory and Practice, 33(2), 481-500. doi:10.1111/j.15406520.2009.00300.x

Bolton, D.L., Lane, M.D. (2012). Individual Entrepreneurial Orientation: development of a measurement instrument. Education + Training, 54(2/3), 219-233. doi:10.1108/00400911211210314

Brandstätter, H. (2011). Personality aspects of entrepreneurship: A look at five meta-analyses. Personality and Individual Differences (Special Issue on Personality and Economics), 51(3), 222230. doi:10.1016/j.paid.2010.07.007

do Paço, A., Matos Ferreira, J., Raposo, M., Gouveia Rodrigues, R., Dinis, A. (2015). Entrepreneurial intentions: is education enough? International Entrepreneurship and Management Journal, 11(1), 57-75. doi:10.1007/s11365-013-0280-5

Espíritu-Olmos, R., Sastre-Castillo, M.A. (2015). Personality traits versus work values: Comparing psychological theories on entrepreneurial intention. Journal of Business Research, 68(7), 1595-1598. doi:10.1016/j.jbusres.2015.02.001

Hatak, I., Harms, R., Fink, M. (2015). Age, job identification, and entrepreneurial intention. Journal of Managerial Psychology, 30(1), 38-53. doi:10.1108/JMP-07-2014-0213

Hisrich, R.D., Peters, M.P., Shepherd, D.A. (2008). Entrepreneurship, 7th ed., Zagreb: Mate. (in Croatian)

Hisrich, R.D., Langan-Fox, J., Grant, S. (2007). Entrepreneurship research and practice: A call to action for psychology. American Psychologist, 62, 575-589. doi:10.1037/0003-066X.62.6.575

Hsu, D.K., Shinnar, R.S., Powell, B.C., Coffey, B.S. (2017). Intentions to reenter venture creation: The effect of entrepreneurial experience and organizational climate. International Small Business Journal: Researching Entrepreneurship, 35(8), 928948.

Hyytinen, A., Ilmakunnas, P. (2007). Entrepreneurial Aspirations: Another Form of Job Search? Small Business Economics, 29(1-2), 63-80. doi:10.1177/0266242616686646

Kickul, J. (2001). Promises Made, Promises Broken: An Exploration of Employee Attraction and Retention Practices in Small Business. Journal of Small Business Management, 39(4), 320-335. doi:10.1111/0447-2778.00029

Kwong, C., Thompson, P. (2016). The When and Why: Student Entrepreneurial Aspirations. Journal of Small Business Management, 54(1), 299-318. doi:10.1111/jsbm.12146

Leppel, K. (2016). The incidence of self-employment by sexual orientation. Small Business Economics, 46(3), 347-363. doi:10.1007/s11187-016-9699-8

Liñán, F., Chen, Y.W. (2009). Development and CrossCultural Application of a Specific Instrument to Measure Entrepreneurial Intention.

Entrepreneurship Theory and Practice, 33(3), 593617. doi:10.1111/j.1540-6520.2009.00318.x

Lüthje, C., Franke, N. (2003). The 'making' of an entrepreneur: testing a model of entrepreneurial intent among engineering students at MIT. $R \& D$ Management, 33(2), 135-147. doi:10.1111/14679310.00288

Malebana, M.J. (2017). Knowledge of entrepreneurial support and entrepreneurial intention in the rural provinces of South Africa. Development Southern Africa, 34(1), 74-89. doi:10.1080/0376835X.2016.1259990

Mali, P., Kuzmanović, B., Nikolić, M., Mitić, S., Terek, E. (2019). Model of leadership and entrepreneurial intentions among employed persons. International Journal of Simulation Modeling, 18(3), 385-396. doi:10.2507/IJSIMM18(3)471

Monsen, E., Boss, R.W. (2009). The Impact of Strategic Entrepreneurship Inside the Organization: Examining Job Stress and Employee Retention. Entrepreneurship Theory and Practice, 33(1), 71104. doi:10.1111/j.1540-6520.2008.00281.x

Mortan, R.A., Ripoll, P., Carvalho, C., Bernal, M.C. (2014). Effects of emotional intelligence on entrepreneurial intention and self-efficacy. Journal of Work and Organizational Psychology, 30(2014), 97-104. doi:10.1016/j.rpto.2014.11.004

Mueller, S.L., Thomas, A.S. (2001). Culture and entrepreneurial potential: A nine country study of locus of control and innovativeness. Journal of Business Venturing, 16(1), 51-75. doi:10.1016/S0883-9026(99)00039-7

Muzychenko, O. (2008). Cross-cultural entrepreneurial competence in identifying international business opportunities. European Management Journal, 26(6), 366-377. doi:10.1016/j.emj.2008.09.002 
Naktiyok, A., Karabey, C.N., Gulluce, A.C. (2010). Entrepreneurial self-efficacy and entrepreneurial intention: the Turkish case. International Entrepreneurship and Management Journal, 6(4), 419-435. doi:10.1007/s11365-009-0123-6

Obschonka, M., Stuetzer, M. (2017). Integrating psychological approaches to entrepreneurship: the Entrepreneurial Personality System (EPS). Small Business Economics, 49(1), 203-231. doi:10.1007/s11187-016-9821-y

Paul, J., Shrivatava, A. (2016). Do young managers in a developing country have stronger entrepreneurial intentions? Theory and debate. International Business Review, 25(6), 1197-1210. doi:10.1016/j.ibusrev.2016.03.003

Pfeifer, S., Šarlija, N., Zekić Sušac, M. (2016). Shaping the Entrepreneurial Mindset: Entrepreneurial Intentions of Business Students in Croatia. Journal of Small Business Management, 54(1), 102-117. doi:10.1111/jsbm.12133

Rafferty, A.E., Griffin, M.A. (2006). Perceptions of organizational change: A stress and coping perspective. Journal of Applied Psychology, 91(5), 1154-1162. doi:10.1037/0021-9010.91.5.1154

Rajković, J., Nikolić, M., Ćoćkalo, D., Terek, E., Božić, S. (2020). National culture and the entrepreneurial intentions of students in Serbia. Journal for East European Management Studies, 25(1), 105-141. doi:10.5771/0949-6181-2020-1-105

Sajfert, Z., Ćoćkalo, D. (2018). Entrepreneurship, Revised ed. Zrenjanin: Tehnički fakultet "Mihajlo Pupin”. (in Serbian)
Santos, F.J., Roomi, M.A., Liñán, F. (2016). About Gender Differences and the Social Environment in the Development of Entrepreneurial Intentions. Journal of Small Business Management, 54(1), 4966. doi:10.1111/jsbm. 12129

Schlaegel, C., Koenig, M. (2014). Determinants of Entrepreneurial Intent: A Meta-Analytic Test and Integration of Competing Models. Entrepreneurship Theory and Practice, 38(2), 291-332. doi:10.1111/etap. 12087

Shinnar, R.S., Giacomin, O., Janssen, F. (2012). Entrepreneurial Perceptions and Intentions: The Role of Gender and Culture. Entrepreneurship Theory and Practice, 36(3), 465-493. doi:10.1111/j.1540-6520.2012.00509.x

Shneor, R., Metin Camgöz, S., Bayhan Karapinar, P. (2013). The interaction between culture and sex in the formation of entrepreneurial intentions. Entrepreneurship \& Regional Development An International Journal, 25(9-10), 781-803. doi:10.1080/08985626.2013.862973

Siu, W., Lo, E.S. (2013). Cultural Contingency in the Cognitive Model of Entrepreneurial Intention. Entrepreneurship Theory and Practice, 37(2), 147173. doi:10.1111/j.1540-6520.2011.00462.x

Tkachev, A., Kolvereid, L. (1999). Self-employment intentions among Russian students. Entrepreneurship \& Regional Development An International Journal, 11(3), 187-215. doi:10.1080/089856299283209

\title{
POREĐENJE PREDUZETNIČKIH NAMERA STUDENATA I ZAPOSLENIH
}

\begin{abstract}
Rad se bavi poređenjem preduzetničkih namera među studentima i zaposlenima u Srbiji. Putem t-testa vrši se poređenje individualnih dimenzija preduzetničke orijentacije, dimenzije postignuća i teorije planiranih dimenzija ponašanja (uključujući dimenziju preduzetničkih namera ) između studenata i zaposlenih. U analizu je uključen pol ispitanika kao kontrolna varijabla. Glavni zaključci su: 1. Dimenzije preuzimanja rizika, proaktivnosti i postignuća imaju statistički značajno veće srednje vrednosti za zaposlene nego za studente . Studenti imaju statistički značajno veće srednje vrednosti sledećih dimenzija : Lični stav, Subjektivna norma i Preduzetnička namera. Dimenzije Inovativnosti i Percipirana kontrola ponašanja podjednako su prisutni i kod studenata i kod zaposlenih. 2. Rezultati za studente ženskog pola i zaposlene ženskog pola pokazuju identične rezultate kao i za ukupan uzorak. Rezultati za studente muškog pola i zaposlene muškog pola razlikuju se po tome što kod zaposlenih stavovi o preduzetništvu ostaju visoki iako imaju posao. 3. Kod dimenzija Lični stav i Ppreduzetnička namera, veće srednje vrednosti su dobijene kod studenata muškog pola, zatim kod studenata ženskog pola, i kod zaposlenih muškog pola, a najniže srednje vrednosti kod zaposlenih ženskog pola. 4. Najmanje razlike između preduzetničkih stavova i namera postoje kod studenata muškog pola, a najveće razlike između preduzetničkih stavova i namera javljaju se kod zaposlenih muškog pola.
\end{abstract}

Ključne reči: Individualna preduzetnička orijentacija; Dostignuće; Teorija planskog ponašanja; Studenti; Zaposleni; Pol; Srbija. 